\title{
Evaluation of Spermatological Parameters Used to Predict the Fertility of Frozen Bull Semen
}

\author{
By H. Kjastad, E. Ropstad and K. Andersen Berg \\ NRF-Norwegian Cattle Association, Hamar, and Department of Reproduction and Forensic Medicine, Nor- \\ wegian College of Veterinary Medicine, Oslo, Norway.
}

\begin{abstract}
Kjæstad, H., E. Ropstad and K. Andersen Berg: Evaluation of spermatological parameters used to predict the fertility of frozen bull semen. Acta vet. scand. 1993, 34, 299. 303. - Post-thaw motility, velocity and acrosome integrity of frozen semen were determined in 18 bulls with varying fertility (average non-return rates: $71.3( \pm 2.8)$ - range: 65.2-75.7). Five semen straws were investigated from each bull. The average values for sperm motility (percentage motile spermatozoa), sperm velocity (graded from 0-3) and acrosome integrity (proportion of spermatozoa with intact acrosome) were $67.5 \%, 2.5$ and $79.3 \%$, respectively. Significant correlations were found between sperm motility and velocity, but not between sperm motility and acrosome integrity. Both sperm motility and velocity were significantly related to bull fertility. It was concluded that of the post-thaw semen characteristics investigated in this study these 2 parameters provided a reliable basis for prediction of bull fertility.
\end{abstract}

motility; velocity; acrosome integrity; non-return rate; AI.

\section{Introduction}

The economic importance of a high breeding efficiency in dairy cows emphasizes the benefit of accurate prediction of the post-thaw fertility of frozen bull semen. Evaluation of the quality of frozen semen has been based on a variety of test methods, including estimation of motility defined as percentage of progressively motile spermatozoa, sperm velocity, ATP content, and acrosome integrity (Saacke \& White 1972, Steward et al. 1972, Berndtson \& Pickett 1980, Söderquist 1991, Kjastad et al. 1992).

Estimation of motility and velocity is used in routine evaluation of bull semen after thawing. The relationship between these parameters and fertility has been, however, disputed, even though the non-return rate has been found to be positively correlated with the postthaw percentage of motile spermatozoa (Gibson \& Graham 1969, Linford et al. 1976).
Acrosomal integrity, expressed as the percentage of spermatozoa with an intact acrosome, has been used together with motility for evaluation of post-thaw quality of bull semen ( $\mathrm{Gil}$ bert \& Almquist 1978). The assessment of acrosomal integrity is facilitated by staining techniques, of which metachromatic staining of the acrosome has been used to detect membranous injuries in this structure (Oettle 1986). The non-return rate is a reliable measure of fertility, provided that a sufficient number of cows is inseminated with each bull or sample of semen. The objective of the present investigation was to study the correlation between post-thaw sperm motility, velocity, and acrosome integrity and the relationship of these parameters to the non-return rate in a large scale insemination programme, in order to test their value with regard to predicting fertility of the bulls. 


\section{Materials and methods \\ Animals}

A total of 18 bulls was selected from a population of 123 young bulls which were being tested for use in the artificial insemination of Norwegian Red Cattle (NRF). The 60-day non-return (NR) rates corrected for season and year of lactation were estimated on the basis of an average of 917 inseminations per bull (range 713-1146), and the average NR value was $71.3 \%( \pm 2.8)$ with a range from 65.2 to $75.7 \%$.

\section{Selection of straws and semen treatment}

The semen was frozen in minipailletes $(0.22$ $\mathrm{ml}$ ) after a final dilution to a sperm concentration of about $120 \times 10^{6}$ per ml with $11 \%$ skim milk containing $7 \mathrm{vol} \%$ glycerol and $5 \mathrm{vol} \%$ egg yolk, and an equilibration and adaption period of $4 \mathrm{~h}$ at $5^{\circ} \mathrm{C}$.

After freezing, 5 straws were selected at random from each bull. Each straw represented different ejaculates used for artificial insemination. The straws contained an insemination dose of approx. $26 \times 10^{6}$ spermatozoa. Thawing of the semen was performed in a water bath at $35^{\circ} \mathrm{C}$.

\section{Semen evaluation}

Determination of the percentage of viable spermatozoa and their velocity (graded from 0 to 3 in steps of 0.5 ), was performed at $39^{\circ} \mathrm{C}$ using a phase contrast microscope (magnification $400 \times)$. From 3 different locations in each straw (top - end normally clipped, middle and bottom) 3 observations were made in phase contrast microscope at $35^{\circ} \mathrm{C}$ independently by 2 operators. Based on these subjective observations the mean percentage of motile spermatozoa and mean sperm velocity was calculated for each straw and each animal.

Evaluation of acrosome integrity was performed using a light microscope (magnifica- tion $1000 \times$ ) after fixation and staining with Spermac $^{\circledR}$ (Stain Enterprises, Rep. of South Africa). Two smears were prepared from each straw (top and bottom), and 100 spermatozoa were evaluated from each smear by a single operator. Acrosome integrity was expressed as the percentage of spermatozoa with an intact acrosome.

\section{Statistical analysis}

Differences between means were assessed by the Fisher-Irwin and the Kruskall-Wallis Test (Chi-square Approximation). Correlation analysis (Spearman correlation coefficient) was used to assess the relationship between semen characteristics and the relationship between these characteristics and fertility.

\section{Results}

The average percentage of motile sperm cells was 67.5 , ranging from $59.9 \%$ to $74.7 \%$ between bulls. Corresponding values for sperm velocity (graded from $0-3$ ) and acrosome integrity (percentage of sperm cells with an intact acrosome) were 2.5 (range 1.5 - 3.0) and $79.3 \%$ (range $62.4-93.5$ ), respectively. Sperm motility and velocity were highly intercorrelated, whilst the correlation coefficients between these 2 parameters and acrosome integrity were rather low (Table 1$)$.

Table 1. Correlation matrix (Spearman correlation coefficients) for the relationship between semen charactertistics. Average values for each straw were used $(\mathrm{n}=90)$.

\begin{tabular}{lccc}
\hline & Motility & Velocity & $\begin{array}{c}\text { Acrosome } \\
\text { integrity }\end{array}$ \\
\hline Motility & - & & \\
Velocity & $0.54^{* * *}$ & - & \\
$\begin{array}{l}\text { Acrosome } \\
\text { integrity }\end{array}$ & $0.16^{\text {n.s. }}$ & $0.26^{* *}$ & - \\
\hline
\end{tabular}

Level of significance. ${ }^{* * *}$ : $\mathrm{p}<0.001,{ }^{* *}: \mathrm{p}<0.01$, n.s.: not significant. 
Table 2. Effect of sampling site on semen quality.

\begin{tabular}{lcccc}
\hline $\begin{array}{l}\text { Sampling } \\
\text { site within } \\
\text { the straw }\end{array}$ & $\mathrm{N}$ & $\begin{array}{c}\text { Motility } \\
\text { mean } \pm \mathrm{SD}\end{array}$ & $\begin{array}{c}\text { Velocity } \\
\text { mean } \pm \mathrm{SD}\end{array}$ & $\begin{array}{c}\text { Acrosome } \\
\text { integrity } \\
\text { mean } \pm \mathrm{SD}\end{array}$ \\
\hline Top & 90 & $65.7^{\mathrm{a}} \pm 10.7$ & $2.5^{\mathrm{a}} \pm 0.5$ & $78.8^{\mathrm{a}} \pm 12.5$ \\
Middle & 90 & $67.5^{\mathrm{ab}} \pm 9.0$ & $2.5^{\mathrm{a}} \pm 0.7$ & - \\
Bottom & 90 & $69.4^{\mathrm{b}} \pm 7.0$ & $2.5^{\mathrm{a}} \pm 0.6$ & $79.8^{\mathrm{a}} \pm 14.3$ \\
\hline
\end{tabular}

Means within column with different superscript differ significantly $(\mathrm{p}<0.05)$.

Selecting observations from the same location in each straw did not significantly change the correlations between the semen characteristics. The motility, however, differed significantly $(\mathrm{p}<0.05)$ between semen collected near the top $(65.7 \%)$ and the bottom $(69.4 \%)$ of the straw (Table 2).

Selection of the 6 bulls with the highest nonreturn rates and the 6 with the lowest for comparison of sperm parameter values, revealed a significant relationship between fertility and semen quality evaluated on the basis of motility and velocity (Table 3 ). The correlation coefficients of these 2 parameters and of acrosome integrity to non-return rate were 0.55 $(\mathrm{p}<0.02), 0.64(\mathrm{p}<0.01)$ and $0.45(\mathrm{p}<0.06)$ respectively.

\section{Discussion}

Sperm motility and sperm velocity reflect 2 different aspects of flagellar activity, both relying on the function of the axonemal complex. The significant correlation between these parameters is therefore to be expected, even if this is reported to depend on the duration of post-thaw storage of frozen bull semen (O'Connor et al. 1981). The low correlation between sperm motility and velocity on the one hand, and acrosome integrity on the other, is in accordance with the results of earlier post-thaw examinations of spermatozoa from the bull and from other species (Gilbert \& Almquist 1978, Narashima et al. 1986, Zalewski \& Andersen Berg 1983), but not with those of a later study of bull semen (Richardson et al. 1992).

The site of sampling within the straw did not appear to affect velocity and acrosome integrity, but the sperm motility differed significantly. This may indicate different freezing and thawing conditions within the straw. Comparisons between straws should therefore be based on standardised sampling procedures.

The value of motility estimations as a method for assessment of the fertilizing capacity of bull spermatozoa has been disputed (Linford et al. 1976, Graham et al. 1978 1980, Söderquist

Table 3. Semen characteristics indicated by motility, velocity (graded from $0-3$ in steps of 0.5 ) and acrosome integrity, in relation to bull fertility.

\begin{tabular}{|c|c|c|c|c|c|}
\hline \multirow[b]{2}{*}{$\begin{array}{l}\text { Bull } \\
\text { fertility }\end{array}$} & \multirow[b]{2}{*}{$\mathrm{N}$} & \multirow[b]{2}{*}{$\begin{array}{l}\text { NR\% Mean } \\
\pm \mathrm{SD}\end{array}$} & \multicolumn{3}{|c|}{$\begin{array}{c}\text { Semen characteristics } \\
\text { Mean } \pm \text { SEM }\end{array}$} \\
\hline & & & $\begin{array}{l}\text { Motility } \\
\%\end{array}$ & Velocity & $\begin{array}{r}\text { Acrosome } \\
\text { integrity, \% }\end{array}$ \\
\hline High & 6 & $74.1^{\mathrm{a}} \pm 1.6$ & $70.3 \mathrm{a} \pm 0.9$ & $2.8^{\mathrm{a}} \pm 1.5$ & $81.8^{\mathrm{a}} \pm 4.8$ \\
\hline Low & 6 & $68.2^{\mathrm{b}} \pm 1.9$ & $64.6^{b} \pm 1.6$ & $2.3^{b} \pm 0.7$ & $73.5^{\mathrm{a}} \pm 7.6$ \\
\hline
\end{tabular}

a, b: Means within columns with different superscript differ significantly ( $p<0.05$, Kruskal-Wallis Test). NR $\%=60$ day non-return rate. 
1991). Nevertheless sperm motility is a critical factor in processes prerequisite to gamete interaction, and a decrease in post-thaw sperm velocity as well as in the proportion of progressing motile cells clearly reflects cellular damages that could reduce the possibility of fertilization.

Although more objective procedures for in vitro evaluation of semen quality have been advanced (Saacke \& White 1972, Steward et al. 1972, Pace et al. 1981, Söderquist \& Larsson 1985), subjective estimation of sperm motility is still the method most frequently used, both for experimental and practical purposes. Further, the results of experiments conducted to determine the correlation between computerized and conventional evaluations and between these evaluations and non-return rates failed to confirm the advantage of the computerized method in providing a prediction of fertility (O'Connor et al. 1981, Andersson et al. 1992).

The process of freezing and thawing may cause severe damage to membrane structures of the sperm head (Healy 1969, Hofmo \& Andersen Berg 1989), a significant finding considering that the acrosome contains enzymes with a crucial role in the penetration of the zona pellucida and the surrounding cellular investments (Austin 1975, Gwatkin 1977, Bedford et al. 1979). The fertility of frozen bull semen has been reported to be more closely related to acrosome integrity than to motility (Saacke \& White 1972). This was not supported by the results of the present study. The value of acrosome integrity as an additional parameter for prediction of fertility should, however, be judged in the light of the great variation found for this parameter (Table 3 ). In order to establish a more reliable estimate of the relationship between acrosome integrity and fertility, a larger number of animals than what was included in the present study should be investigated. The number of sperms studied from each sample should probably also be increased.

In conclusion, the present study revealed a significant relationship between post-thaw quality of frozen semen evaluted on the basis sperm motility and velocity, and fertility. Further, a reduction in the number of spermatozoa per insemination dose in order to reduce the costs in the production of frozen semen, would enhance the importance of semen quality and thereby probably also accentuate the relationship between spermatological parameters and non-return rate. The low correlation between semen motility and acrosome integrity, combined with a significant relationship of both these parameters to fertility would further emphasize the advantage of assessing both parameters in order to establish a reliable basis for post-thaw estimation of semen quality.

\section{References}

Andersson M, Hellman T, Holmström B-G, Jokinen $L$ : Computerized and subjective assessments of post-thaw motility of semen from Finnish Ayrshire Ai bulls in relation to non-return rates. Acta vet. scand. 1992, 33, 89-93.

Austin CR: Membrane fusion events in fertilization. J. Reprod. Fert. 1975, 44, 155-166.

Bedford JM, Moore M, Franklin LE: Significance of the equatorial segment of the acrosome of the spermatozoa in eutherian mammals. Exp. Cell. Res. 1979, 119, 119-126.

Berndtson WE, Pickett $B W$ : Evaluation of frozen semen. In: Morrow (ed.): Current Therapy in Theriogenology. W.B. Saunders Comp. Philadelphia, 1980, 337-354.

Gibson CD, Graham EF: The relationship between fertility and post-freeze motility of bull spermatozoa (by pellet freezing) without glycerol. J. Reprod. Fert. 1969, 20, 155-157.

Gilbert GR, Almquist JO: Effects of processing procedure on post-thaw acrosomal retention and motility of bovine spermatozoa packaged in 0.3 
$\mathrm{ml}$ straws at room temperature. J. Anim. Sci. $1978,46,1,225-231$.

Graham EF, Scmehl MKL, Evenson BK, Nelson DS: Viability assays for frozen semen. Cryobiology 1978, 15, 242-244.

Graham EF, Scmehl MKL, Nelson DS: Problems with laboratory assays. Proc. 8th. Tech. Conf. A.I. \& Reprod. N.A.A.B., 1980, 1-8.

Gwatkin RBL: The acrosome reaction. In: Fertilization mechanisms in man and mammals. Plenium Press, New York, 1977, 61-67.

Healy P: Effect of freezing on the ultrastructure of the spermatozoon of some domestic animals. J. Reprod. Fert. 1969, 18, 21-27.

Hofmo PO, Andersen Berg K: Electron microscopical studies of membrane injuries in blue fox spermatozoa subjected to the process of freezing and thawing. Cryobiol. 1989, 26, 124-131.

Kjastad H, Ropstad E, Andersen Berg K: Relationship between $60 \mathrm{~d}$. non-return rates and spermatological parameters used for frozen bull semen. Proc. 12th. Int. Congr. Anim. Reprod. the Hague 1992, vol. 3, 1566-1569.

Linford E, Glover FA, Bishop C, Steward DL: The relationship between semen evaluation methods and fertility in the bull. J. Reprod. Fert. 1976, 47, 283-291.

Narashima Ras AV, Haranath GB, Soma Sekharam $G$, Ramamohana Rao: Effect of thaw rates on motility, survival and acrosomal integrity of buffalo spermatozoa frozen in medium French straws. Anim. Reprod. Sci. 1986, 12, 123-129.

O'Connor MR, Amann RP, Saacke RG: Comparisons of computer evaluations of spermatozoal motility with standard laboratory tests and their use for predicting fertility. J. Anim. Sci. 1981, 53, 5, 1368-1376.

Oettlé EE: Changes in acrosome morphology during cooling and freezing of dog semen. Anim. Reprod. Sci. 1986, 12, 145-150.

Pace MM, Sullivan JJ, Elliott FJ, Graham EF, Coulter $G H$ : Effects of thawing temperature, number of spermatozoa and spermatozoal quality on fertility of bovine spermatozoa packaged in $0.5 \mathrm{ml}$ French straws. J. Anim. Sci. 1981, 53, 3, 693-701. Richardson GF, Donald AW, MacKinnon CE: Com- parison of different techniques to determine the percentage of intact acrosomes in frozen-thawed bull semen. Theriogenology 1992, 38, 557-564.

Saacke RG, White JM: Semen quality tests and their relationship to fertility. Proc. 4th Tech. Conf. on AI \& Reprod. N.A.A.B., 1981, 22-27.

Steward DL, O'Hagan C, Glover FA: The prediction of the fertility of bull semen from laboratory tests. Proc. 7th Int. Congr. Anim. Reprod. \& AI, München, 1972, 2, 1279-1283.

Söderquist L: Sperm characteristics and fertility in dairy A.I. bulls. Thesis. SLU/Repro, Uppsala, 1991.

Söderquist L, Larsson $K$ : Relationship between ATP content and post-thaw motility in bull semen. Acta vet. scand. 1985, 26, 308-312.

Zalewski W, Andersen Berg K: Acrosomal damage caused by processing of frozen semen from the silver fox (Vulpes argenteus) and the blue fox (Alopex lagopus). Zuchthyg. 1983, 18, 22-26.

\section{Sammendrag \\ Bruk av spermatologiske parametre til å bedømme fertiliteten av frossen oksesad.}

Motilitet, bevegelseshastighet og akrosom-integritet ble unders $\varnothing \mathrm{kt}$ etter opptining av frossen sæd fra 18 okser med varierende fertilitet. Gjennomsnittlig ikke-omløpstall var 71.3 \pm 2.8 (variasjon 65.2-75.7). For hver okse ble det unders $\emptyset \mathrm{kt} 5$ strå fra ejakulater som ble brukt til de inseminasjonene som ga grunnlag for beregningen av ikke-omløpstallene.

Gjennomsnittsverdiene for spermiemotilitet, (prosent bevegelige spermier), spermienes bevegelseshastighet (gradert fra 0-3) og akrosomintegriteten (prosent spermier med intakt akrosom) var henholdsvis 67.5, 2.5 og 79.3. Signifikant korrelasjon ble funnet mellom motilitet og bevegelses- hastighet, men ikke mellom motilitet og akrosomintegritet. Verdien av motilitet og bevegelseshastighet var signifikant relatert til oksenes fertilitet. Det kan herav fastslås at en sædunders $\emptyset$ kelse basert på disse to parametrene vil gi et pålitelig grunnlag for å forutsi fertiliteten av de okser som brukes til produksjon av frossen sæd.

(Accepted April 23, 1993).

Reprints may be requested from: H. Kjæstad, NRF - Norwegian Cattle Association, Vangsvegen 121, N-2300 Hamar, Norway. 